\title{
Retraction Note to: Amine functionalized magnetic nanoparticles for removal of oil droplets from produced water and accelerated magnetic separation
}

\author{
Saebom Ko (D) Eun Song Kim · Siman Park • \\ Hugh Daigle • Thomas E. Milner · Chun Huh • \\ Martin V. Bennetzen · Giuliano A. Geremia
}

Published online: 20 November 2021

C) Springer Nature B.V. 2021

Retraction Note to: J Nanopart Res (2017) 19: 132

https://doi.org/10.1007/s11051-017-3826-6

The Editor-in-Chief has retracted this article because it significantly overlaps with a previously published conference paper by the same authors (Ko et al. 2016).

Hugh Daigle disagrees with this retraction. The other authors have not responded to correspondence regarding this retraction.

The original article can be found online at https://doi.org/ 10.1007/s11051-017-3826-6.

S. Ko $(\bowtie) \cdot$ H. Daigle $\cdot$ C. Huh

Department of Petroleum and Geosystems Engineering, University of Texas, Austin, TX, USA

e-mail: saebomko@austin.utexas.edu

\section{E. S. Kim · T. E. Milner}

Department of Biomedical Engineering, University

of Texas, Austin, TX, USA

\section{S. Park}

Department of Civil, Architectural and Environmental Engineering, University of Texas, Austin, TX, USA

M. V. Bennetzen

Maersk Oil Corporate, Københavnsområdet, Denmark

G. A. Geremia

Maersk Oil Research and Technology Centre, Doha, Qatar

\section{Reference}

Ko, Saebom , Kim, Eun Song, Park, Siman , Daigle, Hugh , Milner, Thomas E., Huh, Chun , Bennetzen, Martin V., and Giuliano A. Geremia. "Oil Droplet Removal from Produced Water Using Nanoparticles and Their Magnetic Separation." Paper presented at the SPE Annual Technical Conference and Exhibition, Dubai, UAE, September 2016. https://doi.org/10.2118/181893-MS

Publisher's note Springer Nature remains neutral with regard to jurisdictional claims in published maps and institutional affiliations. 